\title{
PERSEPSI MASYARAKAT TENTANG MAKAM RAJA DAN WALI GORONTALO
}

\author{
Muh. Rusli \\ IAIN Sultan Amai Gorontalo \\ Email: muhammadruslii@yahoo.com
}

\section{Abstract}

This study aims to elucidate the community's perception on royal cemetery in Gorontalo by using the approach of religion phenomenology. The result pointed out that the cemetery was interpreted as human resting place after life. The purpose of cemetery pilgrimage covers religious traveling, praying in efficacious place, pursuing the blessing by praying for the deceased, recalling the goodness of the heroes and the messengers of Islam, and learning the history and ladunni. The way of praying during the cemetery visit can be done either individually or led by a priets. The ritual in visiting the cemetery of Sultan Amai involves graping the water believed to have a blessing, while at Ju Panggola, the water is provided before cemetery and prayed by priests and also take its glebe to get grace. The pilgrims expect to get a grace of life by praying to the King and the saints, appreciating the kindness of Islamic spreaders and heroes, and learning that human beings will die and return to their God.

Penelitian ini bertujuan untuk mengkaji persepsi masyarakat tentang makam raja dan wali Gorontalo dengan menggunakan pendekatan fenomenologi agama. Hasil penelitian menunjukkan bahwa makam dimaknai sebagai tempat peristirahatan manusia setelah alam dunia. Adapun tujuan ziarah makam meliputi: berwisata religi; berdoa di tempat mustajab; mendapatkan berkah dari Allah dengan mendoakan si mayit; mengenang jasa pahlawan dan pembawa Islam; serta untuk belajar sejarah maupun ilmu ladunni. Prosesi pelaksanaan ziarah kubur dilakukan dengan berdoa sendiri atau didoakan oleh imam. Adapun ritual yang menyertai ziarah makam Sultan Amai adalah mengambil 
air sumur yang diyakini memiliki berkah sedangkan di makam Ju Panggola mengambil air kemasan yang ditempatkan di depan makam yang didoakan oleh imam dan mengambil tanah makam untuk mendapatkan keberkahan. Hikmah bagi peziarah antara lain mendapatkan keberkahan hidup dengan mendoakan raja dan para wali Allah, menghargai jasa para pengembang Islam dan para pahlawan; serta mengambil pelajaran hidup bahwa manusia pasti akan mati dan kembali kepada-Nya.

Keywords: perception; cemetery; pilgrimage

\section{Pendahuluan}

Proses Islamisasi Gorontalo tidak lepas dari peran Sultan Amai. Sejarah mencatat bahwa Sultan Amai adalah putra dari raja Dedu yang menggantikan ayahnya pada tahun 1503. Dia memperbesar wilayah taklukan di Teluk Tomini. Di Palasa dia jatuh cinta kepada Owutango, putri raja Bonenato dari kerajaan Gomenjolo. Orang tua putri menerima pinangan sang raja Amai. Putri Owutango mensyaratkan kepada Amai agar anak keturunannya dan seluruh rakyat Gorontalo harus memeluk agama Islam (Yasin, 2013: 101). Penerimaan masyarakat Gorontalo untuk memeluk Islam adalah bentuk ketaatan mereka terhadap raja. Meskipun demikian, bukan berarti Islam mereka hanya sebatas kado pernikahan Sultan Amai kepada istrinya. Hal ini dibuktikan dengan keikhlasan mereka menerima Islam dan menjiwai seluruh aspek kehidupannya.

Dengan metode yang kurang lebih sama dengan apa yang dilakukan oleh Wali Songo di pulau Jawa, raja Amai menjadikan Islam diterima sedikit demi sedikit di Gorontalo. Dia tidak langsung menghapus hukum-hukum adat yang sudah ada, tetapi mengintroduksi nilai-nilai Islam ke dalam hukum-hukum adat tersebut. Prinsip Amai; syara'a hulo-lulo'a to adati (syariat bertumpu pada adat). Di sini ditekankan bahwa sumber hukum utama adalah hukum adat. Dari Owutango, Amai memperoleh putra yang diberi nama Matolodulakiki yang dinobatkan menjadi raja Gorontalo tahun 1550. Perjuangan pertama dan utamanya adalah menjadikan Islam sebagai agama kerajaan. Keimanan Islam yang ditanamkan dengan mantap oleh ibundanya dan para raja kecil dari Gomonjolo menjadikannya sebagai pejuang Islam sejati. Melalui perjuangan yang berat, pada tahun 1563 (13 tahun setelah beliau memerintah), Matolodulakiki berhasil menjadikan Islam sebagai agama resmi kerajaan yang diyakini oleh seluruh rakyat. Pandangan hidup "syara'a hulo-hulo'a to adati (syariat bertumpu pada adat) diperbaharuinya menjadi 
"adati hulo-hulo'a to syara'a, syara'a hulo-hulo'a to Adati" (adat bertumpu pada syariat, syariat bertumpu pada adat). Prinsip hidup ini menempatkan hukum Islam menjadi setara dengan hukum adat (Yasin, 2013: 102). Hal tersebut tergambar pada tata upacara adat Gorontalo, seperti upacara adat kelahiran, perkawinan, penyambutan tamu, penobatan dan pemberian gelar adat dan upacara adat pemakaman (Botutihe \& Daulima, 2003: 2-353).

Dengan demikian, model pengislaman yang dilakukan oleh Sultan Amai dan dilanjutkan oleh anaknya (Matolodulakiki) merupakan model pengislaman yang ramah terhadap budaya. Hal tersebut berimplikasi positif pada pengembangan agama Islam yang mudah diterima oleh masyarakat Gorontalo yang sangat kental akan budaya lokalnya.

Selain Sultan Amai, pengembangan Islam di Gorontalo juga tidak lepas dari jasa seorang guru spriritual yang bernama Syekh Syarif bin Abdul Azis yang datang dari Mekkah ke Gorontalo. Atas jasa mereka Islam dapat berkembang di Gorontalo sampai sekarang. Karena itu pula makamnya ramai dikunjungi peziarah sebagai bentuk penghargaan atas jasa-jasa yang telah ditinggalkannya. Kedua makam tokoh tersebut berdampingan di depan mihrab masjid Hunto yang kini menjadi salah satu cagar budaya di Gorontalo.

Makam lainnya yang ramai dikunjungi masyarakat di Gorontalo bahkan dari luar Gorontalo adalah Aulia Raja Ilato Ju Panggola di Kota Barat Gorontalo. Hal tersebut menandakan bahwa tokoh tersebut memiliki pengaruh yang besar bagi pengembangan Islam di Gorontalo. Menurut Syaifullah Amin, bukan hanya pada hari-hari tertentu, seperti Jumat atau menjelang bulan suci Ramadhan, ada tradisi berziarah masyarakat Gorontalo yang cukup unik. Salah satu keunikan ziarah di Gorontalo adalah tradisi menziarahkan jabang bayi. Tradisi ini berupa acara mengiring bayi yang masih berusia di bawah umur 40 hari ke makam wali, salah satunya adalah ke makam Aulia Raja Ilato Ju Panggola di Kota Barat Gorontalo. Bayi yang diiring ini didoakan di makam wali, kemudian sang bayi diusap-usap dengan air yang telah diberi doa-doa. Makam Ju Panggola atau Aulia Raja Ilato paling banyak dikunjungi masyarakat. Di sekitar makamnya pula terdapat makam-makam warga yang berdomisili di sekitar makam Ju Panggola. Oleh sebab itu tidak heran makam ini banyak dikunjungi (Amin, 2015).

Ziarah makam memiliki dimensi keyakinan dan emosi keagamaan yang mendalam dari para peziarahnya. Mereka yakin, melalui ziarah yang dilakukan ternyata dapat menjadi sarana untuk menyelesaikan persoalan keduniawian, seperti usaha perdagangan dan untuk menyembuhkan penyakit. Ziarah 
makam, ternyata merupakan tradisi yang telah melembaga pada masa praIslam dan kemudian berkembang di nusantara. Ada relevansi tradisi makam wali dengan ziarah ke candi atau tempat keramat lain pada masa pra-Islam (Masyhudi, 1999: 54).

Berziarah ke makam keramat wali atau raja masih menyisakan problem di masyarakat sebab tidak semua peziarah datang hanya sebagai bentuk penghargaan atas jasa raja atau wali tersebut. Berbagai macam niat yang melatarbelakangi ziarah makam muncul berdasarkan persepsi mereka terhadap makam wali tersebut. Untuk itu, penting untuk mengkaji persepsi masyarakat tentang makam keramat wali sehingga dapat memahami fenomena keberagamaan masyarakat setempat.

Tulisan ini fokus pada persepsi masyarakat terhadap makam wali atau raja Gorontalo yang meliputi makam wali Syekh Syarif bin Abdul Aziz, Sultan Amai, dan Raja Ilato Ju Panggola, dengan sub masalah: 1) Bagaimana makna dan tujuan ziarah makam wali dan raja Gorontalo? 2) Bagaimana proses pelaksanaan ziarah pada makam wali Syekh Syarif bin Abdul Aziz, Raja Sultan Amai, dan Raja Ilato Ju Panggola? 3) Bagaimana hikmah di balik pelaksanaan ziarah makam wali Syekh Syarif bin Abdul Aziz, Raja Sultan Amai, dan Raja Ilato Ju Panggola bagi peziarah?

\section{Tinjauan Pustaka}

Keyakinan-keyakinan keagamaan tiada lain merupakan refleksi dari masyarakat itu sendiri, dengan ritual keagamaan yang diperkuat melalui solidaritas kelompok dan kepercayaan pada tatanan moral (Abdullah, dkk. 2008: 3). Ritus atau agama dalam tindakan, memiliki varian yang berbeda dalam impelementasinya dalam masyarakat (Ghazali, 2011: 50). Untuk itu, setiap daerah memiliki karakteristik sendiri dalam memposisikan makam seorang wali. Di Jawa misalnya, menurut hasil penelitian Syam yang mengambil lokasi di Kec. Palang, Tuban, Jawa Timur, dan desa-desa yang berada di wilayah pesisir, yaitu desa Panyuran, Tasikmadu, Kradenan, Gesikharjo, Palang, Glodok, Leran Kulon, Karangagung, dan Pliwetan menunjukkan bahwa ada tiga lokus sakral dalam kehidupan Islam Jawa, yaitu masjid, makam, dan sumur. Ketiga lokus itu dalam konsepsi kebudayaan disebut cultural sphere atau ruang budaya yang mempertemukan berbagai kelompok sosial, yaitu kaum abangan dan santri. Masjid adalah tempat bertemunya kaum santri yang berafiliasi sosial keagamaan NU dan Muhammadiyah, sedangkan sumur dan makam adalah tempat bertemunya kaum abangan dan santri NU (Syam, 2007: 116-117) 
Makam juga menjadi tempat keramat. Di makam-makam Jawa kebanyakan diselenggarakan upacara manganan. Dalam upacara ini, elemen masyarakat, kaum abangan dan santri NU melakukan kegiatan upacara manganan dalam rangka melaksanakan tradisi lokal, membersihkan makam dan mendoakan keluarga yang sudah meninggal. Dahulu upacara ini hanya sekadar kegiatan membawa makanan ke makam dan didoakan oleh modin desa, kemudian sebagian nasi itu dibuang begitu saja di makam. Sekarang, seirama dengan semakin intensifnya gerakan islamisasi acara tersebut ditambah dengan tahlilan atau yasinan, terutama menjelang digelarnya upacara nyadran. Tidak ada yang istimewa di dalam upacara ini, kecuali suatu kenyataan bahwa budaya yang memungkinkan pertemuan keinginan dan keyakinan (Syam, 2007: 119-120).

Bangunan didirikan untuk makam sangat beragam antara budaya yang berbeda. Piramida dalam kebudayaan Mesir Kuno dibangun demikian rupa sehingga sampai sekarang merupakan salah satu keajaiban dunia, adalah menyangkut kematian dan perjalanan hidup sesudah mati. Budaya membalsem mayat lalu disimpan dalam piramida atau gua batu, dan sekeliling mayat ditulisi dengan hyerogliph, semuanya dibangun sedemikian rupa karena keyakinan kepada keabadian kehidupan sesudah mati. Masjid Taj Mahal dibangun oleh Shah Jehan tahun 1632 yang juga merupakan salah satu keajaiban dunia, adalah dalam rangka mengenang istrinya tercinta. Shah Jehan sendiri juga dimakamkan di sisi istrinya. Masjid tersebut dimaksudkan untuk mengabadikan keduanya. Patung-patung orang besar dibangun di beberapa penjuru dunia oleh budaya Timur dan Barat juga untuk memvisualisasikan keabadian (Agus, 2007: 278).

Lain halnya dengan agama dan kebudayaan Wahabi di Saudi Arabia. Segala bangunan dan upacara berlebihan terhadap mayat, walaupun mayat pemimpin, mereka berantas dengan keras. Makam para sahabat Nabi di Makkah dan Madinah tidak ada yang dibangun. Batu nisannya batu kali biasa yang tidak ditulisi sedikit pun tentang siapa yang dimakamkan di setiap makam (Agus, 2007: 278).

Potret kehidupan masyarakat Gorontalo menunjukkan adanya tiga lokus sakral, yaitu masjid, makam, dan sumur yang mirip dengan lokus sakral di Jawa. Di lokasi makam Syekh Maulana Syarif Abdul Aziz dan Sultan Amai juga ditemui masjid Sultan Amai dan sumur keramat peninggalan Syekh Syarif yang berada di dekat masjid. Hal yang sama juga ditemui di pemakaman Raja Ilato di mana masjid berada di sebelah timur makam. Untuk itu, penting untuk mengkaji persepsi masyarakat terhadap makam keramat/wali Gorontalo 
sebagai motivasi bagi peziarah untuk datang ke makam tersebut. Hal inilah yang menjadi signifikansi dari penelitian ini.

\section{Metode}

Penelitian ini termasuk kategori penelitian lapangan yang bersifat deskriptif dengan menggunakan pendekatan fenomenologi agama. Teknik pengumpulan data adalah observasi, wawancara, dokumentasi dan penelusuran referensi.

Fenomenologi berusaha memahami budaya lewat pandangan pemilik budaya atau pelakunya. Menurut paham fenomenologi, ilmu bukanlah value free, bebas nilai dari apapun, melainkan value bound, memiliki hubungan dengan nilai (Endraswara, 2006: 65). Fenomenolog Edmund Husserl menyatakan bahwa obyek ilmu tidak terbatas pada empirik (sensual), melainkan mencakup fenomena yang tidak lain terdiri dari persepsi, pemikiran, kemauan, dan keyakinan subyek yang menuntut pendekatan holistik, mendudukkan obyek penelitian dalam suatu konstruksi peneliti, melihat obyeknya dalam suatu konteks natural, dan bukan parsial (Endraswara, 2006: 67).

Cox (1992: 24) dengan menggunakan konsep Husserl, mendefinisikan fenomenologi agama sebagai sebuah metode yang menyesuaikan prosedur epoché (penundaan penilaian-penilaian sebelumnya) dan intuisi eidetis (melihat ke dalam makna agama) dengan kajian terhadap beragam ekspresi simbolik yang direspons sebagai nilai yang tidak terbatas. Pengertian ini menunjukkan adanya dua unsur pokok yang melekat dalam pendekatan fenomenologi, pertama, epoché yang berasal dari bahasa Yunani yang berarti "menjauh dari" dan "tidak memberikan suara". Husserl menggunakan epoche untuk term bebas dari perasangka. Dengan epoche, kita menyampingkan penilaian, bias, dan pertimbangan awal yang kita miliki terhadap objek. Dengan kata lain, epoche adalah pemutusan hubungan dengan pengalaman dan pengetahuan yang kita miliki sebelumnya (Kuswarno, 2009: 48).

\section{Biografi Syekh Syarif bin Abdul Aziz}

Syekh Syarif bin Abdul Aziz merupakan tokoh spiritual atau dapat pula dikategorikan sebagai wali yang datang ke Gorontalo untuk mengembangkan Islam. Kedatangan Syekh Syarif bin Abdul Aziz ke Gorontalo bukanlah hal yang kebetulan. Menurut Tokoh Adat DK. Usman:

Dikisahkan bahwa Maulana Syekh Syarif bin Abdul Aziz adalah pemegang kunci Ka'bah. Konon setiap Syekh Syarif membuka Ka'bah dia mendapati dua orang yakni seorang laki-laki dan seorang perempuan di dalamnya. Hal tersebut 
membuat syekh Syarif kagum atas kedua orang tersebut. Karena itu, Syekh Syarif bin Abdul Azis pada suatu waktu memutuskan untuk berkunjung ke Gorontalo untuk menemui orang tersebut. Setibanya di pelabuhan Gorontalo, secara kebetulan beliau bertemu dengan seorang kusir yang notabene orang yang sedang dia cari. Orang tersebut adalah Tau Datao. Tau Datao menawarkan diri untuk mengantar Sultan Amai ke tempat tujuannya. Syekh Syarif pun menceritakan bahwa dia sedang mencari seseorang yang dahulu sering dia temui di dalam Ka'bah. Namun Tau Datau belum mengaku bahwa dialah orang yang dicari Syekh Syarif. Akhirnya Tau Datau membawa Syekh Syarif ke rumahnya. Sesampai di rumahnya, waktu itu telah masuk waktu salat. Tau Datau mempersilahkan Syekh Syarif untuk menjadi Imam, saat itulah Syekh Syarif tahu bahwa Tau Datau adalah orang yang dia cari. Mereka pun akhirnya berdiskusi dan Syekh Syarif memutuskan diri untuk tinggal di Gorontalo untuk mengajarkan Islam. (Wawancara, 4 Agustus 2015)

Lain halnya menurut Takmir Masjid Sultan Amai Syamsuri Kaluku yang menyatakan bahwa orang yang ditemui Syekh Syarif di dalam Ka'bah tersebut terdapat beberapa pendapat, ada yang mengatakan Sultan Amai, ada juga yang mengatakan Kali Balunda, ada juga yang berpendapat lain bahwa orang itu adalah kakek Kali Balunda yang memiliki ilmu ladunni. Konon, dengan ilmunya dia bisa ke Mekkah dengan waktu singkat, ikan yang dia bawa dari Gorontalo ke Mekkah belum mati ketika dia sampai (Wawancara, 15 Juni 2015)

Sejarah hidup Syekh Syarif bin Abdul Aziz secara lengkap belum ditemukan namun menurut penuturan DK. Usman, beliau dapat dikategorikan sufi tarekat. Bahkan DK. Usman sendiri mengakui bahwa beliau adalah generasi ketiga belas tarekat Qadiriyah. Hal tersebut mengindikasikan bahwa corak keberagamaan di Gorontalo banyak dipengaruhi oleh tarekat Qadiriyah. Hal ini dapat dibuktikan dengan adanya dzikir dan wirid yang dilantunkan oleh masyarakat setelah salat mengacu pada tarekat Qadiriyah.

Posisi Syekh Syarif bin Abdul Aziz sebagai guru spiritual sangat besar dalam pengembangan Islam di Gorontalo, hanya saja tidak ditemukan data bahwa dia pernah berkeluarga di Gorontalo, sehingga garis keturunannya tidak dapat diketahui. Namun menurut Syamsuri, ke depan penelusuran terhadap keluarga Syekh Syarif bin Abdul Aziz dapat dilakukan, sebab seseorang yang menjadi pemegang kunci Ka'bah bukanlah orang sembarangan. Setidaknya, dapat diasumsikan bahwa dia keluarga kerajaan dan boleh jadi memiliki hubungan kekeluargaan dengan King Abdul Aziz, Raja Arab Saudi. Hasil penelusuran penulis tentang penjaga Ka'bah menunjukkan adanya hubungan

el Harakah Jurnal Budaya Islam Vol.18 No.1 Tahun 2016 
yakni nama Abdul Aziz yang turun temurun dipegang oleh keluarga Abdul Aziz. Namun temuan awal tersebut masih perlu dikembangkan untuk kepastiannya. Adapun corak keberagamaan yang dikembangkan adalah corak tarekat atau tepatnya tarekat Qadiriyah. Menurut DK. Usman corak keberagamaan di Gorontalo yang dikembangkan oleh Syekh Syarif sampai sekarang merupakan corak tarekat. Hal ini dapat dibuktikan dari wirid-wirid yang dibacakan pada saat selesai salat di masjid-masjid dan acara ritual agama lainnya (Wawancara, 20 Juli 2015). Hal yang sama diungkapkan oleh Umar Abu Bakar, pembaca doa di makam Ilato Ju Panggola yang menyatakan bahwa dalam doa di makam disebutkan namanya Abdul Qadir al-Jilani sebagai wasilah (Wawancara, 19 Juli 2015).

Dengan demikian, mayoritas corak keberagamaan keberislaman masyarakat di Gorontalo sangat kental dengan nuansa sufistik/tarekat. Dan hal tersebut dapat dinyatakan sebagai bentuk keberhasilan dari Syekh Syarif bin Abdul Aziz dalam mengembangkan tarekat Qadiriyah di Gorontalo.

\section{Biografi Sultan Amai}

Sultan Amai merupakan raja pertama yang memeluk Islam dan diikuti oleh rakyatnya, Menurut penuturan Syamsuri Kaluku:

Setelah mendirikan masjid Hunto, Sultan Amai mengumpulkan seluruh rakyatnya di masjid tersebut untuk diislamkan. Pada waktu itu masyarakat Gorontalo masih memeluk kepercayaan Alifuru (sistem kepercayaan yang menyembah roh dan benda-benda yang dianggap bertuah). Setelah terkumpul, Sultan Amai memerintahkan untuk menyembelih seekor babi dan darahnya ditempelkan di seluruh kening rakyatnya yang hadir pada waktu itu. Upacara tersebut dikenal dengan nama upacara sumpah adat "Bontho" akronim bahasa daerah yakni bolo yingoyingontiyolo monga boyi (ini hari terakhir kita makan babi). Larangan makan babi sebagai bentuk perlambang bahwa mereka menerima Islam sebagai agama mereka. Dan bagi yang melanggar sumpah tersebut akan mengalami berbagai macam musibah, meninggal atau terserang penyakit yang tidak bisa disembuhkan (Wawancara, 15 Juni 2015).

Sumber lain menyebutkan bahwa semasa berkuasa, Amai beserta delapan raja di daerah itu itu melahirkan 185 rumusan adat mencakup upacara perkawinan dan kematian, perilaku berkeluarga, bermasyarakat penerimaan tamu dan penobatan pemimpin. Hasil rumusan itu dikenal dengan prinsip Saraa Topa-Topango to Adati atau syariat (hukum Islam) bertumpu pada adat (http:// degorontalo.co/sumpah-bontho-sejarah-orang-gorontalo-masuk-islam/ akses 22 Agustus 2015). 
Dalam buku berjudul "Memori Gorontalo; Teritori, Transisi dan Tradisi" karya Basri Amin, disebutkan aksara Arab sudah dipakai di Gorontalo sejak 1525. Prinsip adat yang digagas oleh Amai, kemudian disempurnakan pada masa pemerintahan Raja Eyato yang berkuasa pada 1673-1679, menjadi Adati Hulahulaa To Saraa, Saraa Hulahulaa To Quruani yang berarti Adat Bersendi syariat, syariat bersendi Kitabullah (al-Qur'an) menjadi falsafah yang hingga saat ini dipegang oleh warga Gorontalo. Makamnya yang terletak di belakang masjid bersejarah itu pada waktu-waktu tertentu, juga kerap dikunjungi banyak orang dari berbagai penjuru daerah, termasuk pada bulan Ramadhan. Di batu nisannya, Sultan Amai diberi gelar Ta Olongia Lopo Isilamu (Raja yang menyebarkan agama Islam) (Terrajana, 2015).

Terkait penetapan makam Sultan Amai, D.K. Usman menyatakan bahwa: Pada dasarnya penetapan makam Sultan Amai di depan masjid Hunto merupakan petunjuk dari guru tarekatnya yang bernama Syawal. Dengan demikian, tidak diragukan lagi bahwa di depan masjid Hunto itulah Sultan Amai dimakamkan (Wawancara, 23 Juli 2015).

Dengan demikian, lokasi makam Sultan Amai adalah di depan mihrab/ mesjid Hunto. Belum didapatkan pandangan lain terkait lokasi tersebut. Hal yang sama juga terjadi pada makam Raja Ilato Ju Panggola, yang sebelumnya tidak diketahui keberadaannya. Namun suatu ketika mucul makam di atas perbukitan yang kemudian diyakini oleh masyarakat sebagai makam tokoh tersebut. Sampai hari ini, belum ada laporan penelitian atau temuan masyarakat yang menyatakan bahwa makamnya ada di tempat lain. Sehingga, baik makam wali Syekh Syarif bin Abdul Aziz, Sultan Amai, dan Raja Ilato Ju Panggola masih tetap diyakni berada di lokasi tersebut.

\section{Biografi Raja Ilato Ju Panggola}

Ju Panggola adalah seorang ulama, pejuang dan orang saleh yang masyhur di abad ke 16. Pendek kata Ju Panggola adalah tokoh kharismatik yang makamnya dikeramatkan, dan sampai sekarang selalu dikunjungi banyak orang. Sebagai penghormatan, makam Ju Panggola dibangun di balik mihrab Masjid Quba - sebuah masjid mungil, di puncak sebuah bukit dengan panorama yang indah di sekitarnya.

Menurut Farha Daulima, Ketua Badan Pengelola Lembaga Pariwisata Banthayo Pobo'ide, Ju Panggola sesungguhnya adalah gelar, yang artinya "tokoh yang dituakan". Orang Gorontalo di zaman dahulu selalu mengenal Ju Panggola sebagai kakek tua yang berjubah putih yang panjangnya sampai ke lutut. Dia juga dikenal sebagai Ilato. Alias "Kilat", karena perjuangan melawan 
penjajah Belanda dia mampu menghilang, dan kembali muncul jika negeri dalam keadaan gawat. Karena jasa-jasanya, Ju Panggola mendapat gelar adat "Ta Lo'o Baya Lipu" atau orang yang berjasa kepada rakyat", sebagai lambang kehormatan dan keluhuran negeri.

Ju Panggola juga dikenal sebagai penyebar agama Islam. Berkat penguasaan ilmu agama yang tinggi, dia tidak saja dikenal sebagai ulama, tapi juga sebagai wali. Sebagai pejuang, dia juga dikenal sebagai pendekar yang piawai dalam ilmu persilatan yang di Gorontalo disebut Langga. Berkat kesaktiannya, dia tidak perlu melatih murid-muridnya secara fisik, melainkan cukup dengan meneteskan air kepada kedua bola mata sang murid, dan setelah itu, kontan sang murid mendapatkan jurus-jurus silat yang mengagumkan. Tapi ada versi legenda lain yang menyebutkan bahwa Ilato adalah "Raja". Namun tidak ada yang dapat memastikan, apakah Ilato Ju Panggola adalah juga Raja Ilato putra Raja Amai yang bergelar "Matoladulakiki" yang memerintah kerajaan Gorontalo pada 1550 - 1585, dan menetapkan Islam sebagai agama resmi kerajaan. Yang pasti, pada sebuah batu prasasti di bukit yang juga merupakan fondasi masjid Quba, tertera tulisan: Masjid Quba, tempat makam Ta'awuliya Raja Ilato Ju Panggola, Ta Lo'o Baya Lipu, 1673 M, wafat Ahad 1 Muharam 1084 H.

Seperti halnya banyak legenda, sebuah versi mengatakan, Ju Panggola wafat di Mekah. Tapi versi lain menyebutkan, dia tidak wafat, melainkan raib, menghilang secara gaib. Lantas bagaimana dengan makam di balik mihrab masjid Quba yang diyakini sebagai makam Ju Panggola? Menurut Farha Daulima, makam tersebut dibangun oleh warga setempat hanya berkat adanya keajaiban di tanah tempat makam itu kini berada. Tanah yang berwarna putih itu baunya sangat harum. Menurut penuturan orang-orang tua dahulu, Ju Panggola pernah berwasiat, "Dimana ada bau harum dan tanahnya berwarna putih di situlah aku," di sana pula dahulu Ju Panggola tinggal sekaligus berkhalwat. Itulah sebabnya warga setempat menganggap, di sana pula Ju Panggola "beristirahat panjang". Makam Ju Panggola terdapat dalam sebuah bilik berukuran 3 × $3 \mathrm{M}$, lantainya dari keramik warna putih, sewarna dengan kain kelambu penutup tembok dinding yang menjuntai menyentuh lantai. Sebuah kipas angin menempel di plafon makam (Ju Panggola, 2012)

Sampai hari ini makamnya ramai dikunjungi masyarakat Gorontalo bahkan dari luar Gorontalo. Bukan hanya pada hari-hari tertentu, seperti Jumat atau menjelang bulan suci Ramadhan, ada tradisi berziarah masyarakat Gorontalo yang cukup unik. Salah satu keunikan ziarah di Gorontalo adalah tradisi menziarahkan jabang bayi. Tradisi ini berupa acara mengiring seorang 
bayi yang masih berusia di bawah umur 40 hari ke makam wali, salah satunya adalah ke Makam Aulia Raja Ilato Ju Panggola di Kota Barat Gorontalo. Bayi yang diiring ini didoakan di makam wali, kemudian dang bayi diusap-usap dengan air yang telah diberi doa-doa. Makam Ju Panggola atau Aulia Raja Ilato paling banyak dikunjungi masyarakat. Di sekitar makamnya terdapat makam-makam warga yang berdomisili di sekitar makam Ju Panggola. Oleh sebab itu tak heran makam ini banyak dikunjungi (Amin, 2015).

\section{Makna dan Tujuan Ziarah Makam Wali dan Raja Gorontalo}

Makna dan tujuan ziarah makam wali dan raja Gorontalo bagi peziarah tergantung pada persepsi mereka tentang makam itu sendiri. (Kotler, 2000: 32) menjelaskan persepsi sebagai proses bagaimana seseorang menyeleksi, mengatur dan menginterpretasikan masukan-masukan informasi untuk menciptakan gambaran keseluruhan yang berarti.

Persepsi adalah suatu pengenalan ataupun identifikasi dengan menggunakan panca- indra. Kesan yang diterima oleh individu sangat tergantung pada seluruh pengalaman yang telah diperoleh melalui proses berpikir dan belajar serta dipengaruhi oleh faktor yang berasal dari dalam individu, persepsi juga diartikan sebagai suatu proses dimana individu mencoba mengorganisasikan serta mengartikan stimulus yang diterima melalui inderanya menjadi suatu makna. Terdapat beberapa faktor yang mempengaruhi persepsi yaitu faktor personal dan faktor struktural. Faktor personal antara lain adalah, proses belajar, motif, dan kebutuhan, sedangkan faktor struktural meliputi lingkungan, dan nilai sosial dalam masyarakat (Arisandi, 2011: 14).

Pada umumnya, hasil wawancara dengan peziarah mengenai makna atau pengertian makam menyatakan bahwa makam adalah tempat peristirahatan setelah alam dunia. Namun dari sisi tujuan mereka sangat variatif, di antaranya:

\section{Pertama, makam sebagai tempat wisata religi;}

Wisata religi yang dimaksudkan menurut hasil wawancara dengan beberapa peziarah adalah kunjungan ke makam untuk mengingatkan diri bahwa pada akhirnya manusia akan kembali kepada Tuhan, bagaimanapun juga manusia pasti mati. Untuk itu, berziarah ke makam dapat menyadarkan kita akan pentingnya hidup sesuai dengan tuntunan agama.

Makam sebagai alternatif tempat wisata merupakan fenomena yang menarik di tengah banyaknya tawaran tempat wisata di Gorontalo. Ketiga makam tersebut tidak hanya ramai dikunjungi pada saat lebaran Idul Fitri, 
Idul Adha, dan Nisfu Sya'ban tetapi juga pada hari-hari biasa, meskipun tidak seramai pada saat lebaran. Selain tidak dipungut biaya masuk, makam juga memberikan kepuasan tersendiri bagi pengunjungnya. Misalnya di makam Ju Panggola, pengunjung dapat melepaskan kepengatan dari rutinitas keseharian dengan menyaksikan keindahan danau Limboto dan menghirup udara segar pegunungan. Di samping itu, mendapatkan pencerahan qalbu dengan menziarahi makam, bahwa hidup hanya sementara, semuanya akan ditinggalkan bila ajal telah menjemput.

Sebagai tempat wisata, hal tersebut membawa pengaruh bagi perekonomian masyarakat setempat dengan membuka kedai-kedai kecil untuk memenuhi kebutuhan pengunjung. Belum lagi anak-anak kecil yang berlarian menyambut pengunjung guna mendapatkan sedekah.

\section{Kedua, sebagai tempat mustajab berdoa;}

Beberapa narasumber (yang meminta namanya tidak disebutkan) menyatakan bahwa makam identik dengan doa. Namun menurutnya bukan berarti syirik, sebab doa yang dimaksud bukan meminta kepada si mayit tetapi mendoakan si mayit. Adapun doa hajat pribadi tetap dilaksanakan di dalam mesjid.

Ada anggapan peziarah bahwa Makam Ju Panggola termasuk makam keramat dan tanah di sekitar makam itu senantiasa menebarkan bau harum. Setiap pengunjung yang berziarah ke makam itu mengambil segenggam tanah untuk dijadikan azimat. Mereka percaya bahwa tanah tersebut dapat menyembuhkan berbagai macam penyakit atau memperlancar rezeki. Ajaibnya, walaupun sudah ribuan pengunjung mengambil tanah di sekitar makam itu, namun tanahnya tetap utuh. Bahkan, tanah bekas galian tersebut tidak meninggalkan bekas lubang sedikit pun. Di dalam komplek makam tersebut terdapat sebuah masjid yang bernama Masjid Ju Panggola. Konon, jika seseorang berdoa di masjid tersebut, permohonannya akan dikabulkan. Maka tidak heran, jika banyak pengunjung yang menyempatkan diri salat dan berdoa untuk memohon kesembuhan dari berbagai penyakit, memperlancar rezeki dan lain sebagainya.

Pengambilan tanah putih di makam Ilato Ju Panggola memang memungkinkan sebab telah disediakan sendok di atas makam tersebut. Dan hal tersebut dibenarkan pula oleh Umar (pemimpin doa) bahwa terkadang ada yang mengambil tanah makam tersebut karena adanya anggapan bahwa 
tanah tersebut membawa berkah. Di samping itu, ada tradisi menziarahkan bayi di makam wali.

Kepada NU Online, Imam Ali Abu Bakar, salah seorang imam, pemuka agama lokal menuturkan, tradisi ini memang bukan suatu keharusan, namun banyak masyarakat menganggap penting untuk menzirahkan bayinya kepada para wali. Tujuan dari menziarahkan bayi ini adalah untuk mengenalkan sang bayi kepada para wali sedini mungkin. Dengan meminta doa dari para pemuka agama di makam para wali, orangtua sang bayi berharap kelak anak mereka tumbuh menjadi pribadi yang berbudi luhur dan selalu tertanam kecintaan kepada para ulama dan wali. (Amin, 2015)

Adanya keyakinan terkait manfaat tanah dari makam Ilato Ju Panggola, adanya praktek menziarahkan bayi, mendapatkan keberkahan hidup dan lainnya tentu saja, bagi mereka hal tersebut bukanlah syirik. Itu semua merupakan upaya untuk mendekatkan diri dengan orang-orang yang dekat dengan Allah semasa hidupnya.

Penyediaan sendok di makam Ju Panggola mengindikasikan adanya pembenaran bahwa tanah makam tersebut bermanfaat bagi pengunjungnya, sehingga tradisi pengambilan tanah makam terus berlanjut sampai sekarang. Meskipun pengakuan mereka hanya sebatas "keberkahan", namun tidak menutup kemungkinan terjadinya tergelincirnya niat akan manfaat dan tujuan tanah makam tersebut oleh penggunanya.

\section{Ketiga, tempat untuk mendapatkan berkah dari Allah dengan mendoakan si mayit}

Menurut para pengunjung makam, salah satu alasan kedatangan mereka ke makam adalah mendapatkan berkah dari Allah dengan mendoakan si mayit. Mereka meyakini bahwa dengan mendoakan orang yang dekat dengan Allah maka mereka pun akan mendapatkan keberkahan hidup.

Hal tersebut dibenarkan oleh Umar Abu Bakar (pemimpin doa di makan Ilato Ju Panggola) yang menyatakan bahwa setiap orang yang datang ke makam Ilato Ju Panggola memiliki maksud dan tujuan yang berbeda. Dari doa keselamatan biasa sampai meminta keberkahan hidup (Wawancara dengan Umar Abu Bakar, 19 Juli 2015).

Hal yang sama juga terjadi pada pengunjung makam Sultan Amai dan Syekh Syarif bin Abdul Aziz, mereka meyakini bahwa dengan menziarahi dan mendoakan si mayit dapat membawa keberkahan pada hidupnya. 
Mendapatkan berkah dari Allah dengan mendoakan si mayit bisa menyebabkan pembenaran anggapan bahwa si mayit memiliki pengaruh terhadap orang yang masih hidup. Hal tersebut bisa menyebabkan mereka meyakini bahwa si mayitlah yang menjadikan doanya diterima. Meskipun sesuai pengakuan mereka, makam masih sebatas wasilah, dan makam wali sebagai wasilah masih menjadi perdebatan di kalangan ulama.

Keempat, sebagai tempat untuk mengenang jasa pahlawan dan pembawa Islam

Dijadikannya masjid Hunto sebagai cagar budaya menjadi daya tarik tersendiri bagi masyarakat tidak terkecuali para pejabat. Kedatangan mereka ke masjid Hunto sekaligus dimanfaatkan untuk berziarah ke makam Sultan Amai dan Syekh Syarif bin Abdul Aziz sebagai pembawa dan pengembang Islam di Gorontalo. Hal tersebut dibenarkan oleh Syamsuri Kaluku yang menyatakan bahwa, selain mahasiswa juga datang rombongan dari para pejabat dari luar daerah yang berkunjung ke Gorontalo sekaligus mengunjungi masjid dan makam-makam bersejarah (Wawancara, 22 Juli 2015).

Kelima, sebagai tempat untuk belajar baik sejarah maupun ilmu ladunni

Arman (mahasiswa/peziarah) menyatakan bahwa kedatangannya ke makam Sultan Amai dan Syekh Syarif untuk menggali sejarah Sultan Amai yang merupakan salah satu pembawa Islam di Gorontalo. Baginya, masyarakat Gorontalo harus mampu mengenal lebih dekat akan tokoh-tokohnya yang telah berjasa bagi pengembangan agama, bangsa dan negara. Pendapat yang sama juga diungkapkan oleh beberapa mahasiswa dari IAIN Sultan Amai Gorontalo yang pernah berkunjung ke makam tersebut.

Menurut Syamsuri, beberapa kali datang rombongan dari mahasiswa jurusan Sejarah untuk menggali sejarah Sultan Amai. Selanjutnya, masjid Sultan Amai dijadikan sebagai tempat i'tikaf bagi peziarah. Menurutnya ada salah seorang peziarah dari Batam yang sampai tinggal selama satu bulan di dalam masjid untuk i'tikaf. Pada akhirnya, menurut pengakuan tersebut, dia telah mendapatkan ilmu ladunni dari kedua tokoh tersebut selama dia beri'tikaf di dalam masjid (Wawancara, 22 Juli 2015). Lebih rinci Syamsuri Kaluku menjelaskan:

Makna ziarah makam wali sangat variatif. Makam atau makam sendiri dimaknai sebagai tempat persemayaman terakhir seorang wali. Ada juga yang memaknai sebagai tempat mustajab atau terkabulnya doa. Sedangkan makna 
ziarah makam tergantung pada keyakinan setiap orang yang datang. Beberapa kali datang rombongan dari mahasiswa jurusan Sejarah untuk menggali sejarah Sultan Amai. Selain mahasiswa juga datang rombongan dari para pejabat dari luar daerah yang berkunjung ke Gorontalo sekaligus mengunjungi masjid dan makam-makam bersejarah.

Berziarah ke makam wali Syekh Syarif bin Abdul Aziz dan Sultan Amai juga ditanggapi beragam oleh masyarakat. Di satu sisi ada yang membolehkan, namun di sisi lain juga ada yang melarang. Menurut Syamsuri, ketika makam kedua tersebut dikukuhkan keberadaannya, maka muncul sekelompok orang yang menolak untuk salat di masjid tersebut dengan alasan bahwa tidak boleh salat di depan makam meskipun itu makam wali. Hal tersebut dinilai bidah yang akan menjerumuskan ke dalam api neraka. Baginya, keberadaan makam di depan mihrab tidak dimaknai salat di makam sebab ada penghalang antara makam dan masjid. Di samping itu, jika berkiblat pada realitas pada makam Nabi saw. yang juga berada dalam area masjid maka seharusnya hal tersebut bukan sesuatu yang harus dipertentangkan oleh umat Islam.

Persepsi masyarakat tentang makam sangat dipengaruhi oleh corak keberagamaan yang sangat sufistik dan keyakinan mereka bahwa menziarahi dan mendoakan orang yang dekat dengan Allah maka kehidupannya pun akan diberkahi oleh Allah. Dan mereka meyakini bahwa perilaku keagamaan seperti itu tidak bertentangan dengan syariat karena mereka yakin bahwa semua doa Allah-lah yang mengabulkannya, bukan si mayit. Menziarahi makam raja atau wali akan membawa pengaruh positif bagi sprititual seseorang bahwa semua manusia nantinya akan kembali kepada Allah.

\section{Proses Pelaksanaan Ziarah}

Menurut Syamsuri, pelaksanaan ziarah ke makam wali Syekh Syarif bin Abdul Aziz dan Sultan Amai cukup variatif. Namun pada umumnya melewati beberapa tahapan: (1.) Salat sunat Tahiyatul Masjid; (2.) Salat tobat; (3.) Berziarah di makam wali, dan (4.) Berziarah di sumur tua yang berada di samping masjid.

Keberadaan sumur tua yang kini dijadikan sebagai sumber mata air untuk berwudhu memiliki kisah mistik yang dihubungkan dengan Syekh Syarif bin Abdul Aziz. Menurut sejarahnya, suatu ketika, terjadi kekeringan di Gorontalo, para jamaah yang ingin melaksanakan salat di masjid Sultan Amai bingung untuk mencari air. Maka dipanggillah Syekh Syarif untuk berdoa di depan sumur yang terletak di sebelah masjid. Syekh Syarif pun

el Harakah Jurnal Budaya Islam Vol.18 No.1 Tahun 2016 
menengadahkan tangan seraya berdoa dan diikuti oleh jamaah, akhirnya keluarlah air dari sumur tersebut sampai meluap ke depan masjid. Akhirnya para jamaah memanggil kembali Syekh Syarif untuk berdoa agar air tersebut berhenti mengalir. Setelah Syekh Syarif berdoa akhirnya air tersebut berhenti mengalir. Sampai sekarang sumur tersebut dimanfaatkan untuk berwudhu, dan sejak itu pula airnya tidak pernah kering meskipun terjadi kekeringan di Gorontalo.

Selain sebagai sumber mata air untuk berwudhu bagi para jamaah, keberadaan sumur tersebut juga memiliki daya tarik bagi para peziarah, sebab di antara mereka ada yang meyakini bahwa air dalam sumur tersebut berkhasiat dalam hal menyembuhkan penyakit. Hal tersebut disampaikan peziarah bahwa setelah mereka mandi dan minum air tersebut, maka walhasil penyakitnya pun hilang.

Dari aspek doa, pada umumnya dipimpin oleh Imam Masjid, namun juga diperbolehkan untuk berdoa sendiri-sendiri, namun dengan tetap memberikan nasihat untuk tidak meminta kepada makam melainkan hanya kepada Allah. Demikian hal yang terjadi di makam Ilato Ju Panggola, setiap peziarah yang datang dapat melaksanakan salat sunat terlebih dahulu, sebab makam berada di lingkungan masjid. Selanjutnya, untuk doanya dapat berdoa sendiri dan dapat pula dibantu oleh pemimpin doa.

Ada fenomena seputar doa yakni adanya masyarakat membawa air kemasan botol untuk diletakkan di depan makan ketika berdoa. Setelah berdoa air tersebut dibawa pulang dan dianggap memiliki berkah. Namun ada pula yang tidak membawa apa-apa. Fenomena lainnya adalah adanya sekumpulan anak-anak, ibu-ibu, dan bapak-bapak yang menunggu sedekah dari para peziarah. Keberadaan mereka menambah ramai makam setiap harinya.

\section{Hikmah di Balik Pelaksanaan Ziarah Makam}

Berdasarkan hasil wawancara dengan berbagai narasumber/peziarah, maka hikmah yang dapat dipetik dari pelaksanaan ziarah makam raja dan wali tersebut adalah:

Pertama, mengenal lebih dekat wali dan raja sebagai orang yang berjasa dalam pengembangan Islam di Gorontalo. Hal tersebut dapat berdampak psikologis bagi umat Islam untuk melanjutkan perjuangan para wali dalam mengembangan Islam di Gorontalo. Juga diharapkan mampu mentransfer sifat-sifat beliau dalam konteks kehidupan bermasyarakat, di mana beliau sangat toleran dan ramah akan budaya lokal dengan slogan syara'a hulo-lulo'a 
to adati (syariat bertumpu pada adat), yang di kemudian hari dikembangkan menjadi adat bersendikan syariat, syariat bersendikan Kitabullah. Pengenalan tersebut dilakukan sejak anak masih bayi. Sehingga kelak mereka tidak lupa dan mampu meneladani tokoh-tokoh tersebut.

Kedua, mengunjungi makam bertujuan untuk mengingat akan kematian. Dengan demikian, hikmah yang dapat dipetik adalah mensyukuri nikmat hidup dengan memanfaatkannya kepada jalan-jalan yang diridhai oleh Allah. Dengan demikian, ziarah kubur dapat dimaknai mendekatkan diri kepada Allah.

Ketiga, manusia harus berdoa dan tempat berdoa dapat dilakukan di tempat yang mustajab doa diterima salah satunya adalah masjid. Sedangkan berdoa di makam adalah mendoakan si mayit yang merupakan orang yang dekat dengan Allah semasa hidupnya. Besar harapan mendoakan mereka akan terkena berkahnya. Adapun mengambil air atau tanah putih hanyalah sebagai media harapan semoga Allah memberikan rahmat-Nya lewat benda tersebut, namun tidak harus dimaknai sebagai bentuk kemusyrikan.

Berdasarkan hikmah ziarah makam menurut peziarah tersebut, maka dapat disimpulkan bahwa persepsi masyarakat terhadap makam adalah sebatas media untuk mendekatkan diri kepada Allah.

\section{Penutup}

Prosesi pelaksanaan ziarah kubur dilakukan dengan berdoa sendiri atau didoakan oleh imam. Adapun ritual yang menyertai di makam Sultan Amai adalah mengambil air sumur sedangkan di makam Ju Panggola tersedia air botol yang ditempatkan di depan makam dan didoakan oleh imam untuk mendapatkan keberkahan; juga mengambil tanah makam sebagai berkah. Hikmah bagi peziarah yaitu untuk mendapatkan keberkahan hidup dengan mendoakan raja dan para wali Allah, menghargai jasa para pengembang Islam dan para pahlawan; serta menjadikan sebagai pelajaran hidup bahwa manusia pasti akan mati dan kembali ke Allah. Bagi peziarah prosesi ziarah makam wali dan raja Gorontalo merupakan hal yang tidak bertentangan syariat Islam dan tidak termasuk perbuatan syirik, namun tentu saja akan berbeda hasilnya bilamana pendekatan yang digunakan dalam meneliti bukan pendekatan fenomenologi agama. Sebab salah satu hal yang mungkin dipermasalahkan oleh sebagian orang adalah mengambil tanah kuburan yang dianggap memiliki keberkahan. Untuk itu, tulisan ini dapat menjadi acuan bagi penelitian selanjutnya.

el Harakah Jurnal Budaya Islam Vol.18 No.1 Tahun 2016 


\section{Daftar Pustaka}

Abdullah, Irwan. dkk. 2008., Agama dan Kearifan Lokal dalam Tantangan Global. Cet. II; Yogyakarta: Sekolah Pascasarjana UGM dan Pustaka Pelajar,

Agus, Bustanuddin. 2007. Agama dalam Kehidupan Manusia -Pengantar Antropologi Agama, Jakarta: PT. Raja Grafindo Persada.

Amin, Syaifullah. Islam Nusantara-Makam Aulia Raja Ilato Ramai Dikunjungi Peziarah. http://www.nu.or.id. 12 Mei 2015.

Arisandi, Ni Gusti Ayu Dewi Paramita. 2011. Persepsi Masyarakat Desa Beraban tentang Program Siaran Pariwisata Budaya di Bali TV sebagai Media Informasi dan Promosi. Tesis, Pascasarjana Udayana Denpasar.

Botutihe, Medi. dan Parha Daulima. 2003. "Tata Upacara Adat Gorontalo - Dari Upacara Adat Kelahiran, Perkawinan, Penyambutan Tamu, Penobatan dan Pemberian Gelar Adat Sampai Upacara Adat Pemakaman". Gorontalo:t.p.

Cox, James L. 1992. Expressing the Sacred: An Introduction to the Phenomenology of Religion, Harare: University of Zimbabwe.

Endraswara, Suwardi. 2006. Metode, Teori, Teknik Penelitian Kebudayaan-Ideologi, Epistemologi, dan Aplikasi. Cet. I; Yogyakarta: Pustaka Widyatama.

Ghazali, Adeng Muchtar. 2011. Antropologi Agama-Upaya Memahami Keragaman Kepercayaan, Keyakinan, dan Agama. Bandung: Alfabeta..

Ju Panggola. 2012 diakses dari www.kpad-gorontalo.pnri.go.id/content/jupanggola-pejuang-dan-wali-gorontalo, 2 September 2015.

Kuswarno, Engkus. 2009. Metodologi Penelitian Komunikasi Fenomenologi-Konsep, Pedoman, dan Contoh Penelitiannya. Cet. I; Bandung: Widya Padjadjaran.

Masyhudi, "Ziarah Makam Sunan Ampel Surabaya (Studi tentang Perubahan Kebudayaan), dalam Madaniyya, Jurnal Sastra dan Sejarah, No. 2/II/1999.

Syam, Nur. 2007. Madzhab-madzhab Antropologi. Yogyakarta: LKiS.

Terrajana, Syam. 2015 diakses dari www.degorontalo.co/sumpah-bonthosejarah-orang-gorontalo-masuk-islam/ 22 Agustus 2015

Yasin, Zohra. 2013. Islam, Tradisi dan Kearifan Lokal. Gorontalo; Sultan Amai Press. 